\title{
CORE STABILITY EXERCISE WITH BALL MENINGKATKAN KESEIMBANGAN PADA PASIEN STROKE DI KLINIK KARMEL (Core Stability Exercise With Ball Improves Balance On Stroke Patients)
}

\author{
Arfian Hamzah ${ }^{1}$, Enny Fauziah ${ }^{1}$, Luluk Maulina ${ }^{2}$ \\ 1 Program Studi DIII Fisioterapi Politeknik Unggulan Kalimantan, Banjarmasin \\ 2Program Studi S1 Fisioterapi Institut Medika Drg. Suherman \\ arfianhamzah@polanka.ac.id
}

\begin{abstract}
Stroke is a clinical manifestation of cerebral dysfunction, both local and global, which lasts rapidly even more than 24 hours. Stroke is a cerebrovascular disease which refers to any sudden neurologic disorder that occurs due to limited or stopping blood flow through the arterial supply of the brain known as Cerebro Vascular Accident (VSA). Patients with stroke will experience balance disorder, balance disorder in stroke people are related to the inability to regulate weight transfer and decreased muscle mobility. Patients with recurrent strokes have problems with postural control, thus hindering the movement. Balance is also a parameter for stroke people on the success of their therapy. This research to proves that core stability exercise with ball improves balance on stroke patients at Karmel Clinic. This research is an experimental study with a pre-test and post-test group design. The sample consisted of 22 people. Exercise is given 3 times a week for 6 weeks. The sampling technique was random sampling. Balance is measured by Berg Balance Scale Questionnaire (BBS questionnaire). The result of this research indicate that the core stability exercise with ball improves balance on stroke patients significantly $(p=0.001)$. So it suggested to physiotherapist apply it to patients with stroke to improves balance.
\end{abstract}

Keyword: Core Stability Exercise, Stroke, Balance

\begin{abstract}
ABSTRAK
Stroke merupakan manifestasi klinis dari disfungsi otak, baik lokal maupun global, yang berlangsung dengan cepat bahkan lebih dari 24 jam. Stroke adalah penyakit cerebrovascular yang mengacu pada gangguan neurologis mendadak yang terjadi karena aliran darah yang terbatas atau terhenti melalui suplai arteri otak yang dikenal dengan Cerebro Vascular Accident (VSA). Penderita stroke akan mengalami gangguan keseimbangan, gangguan keseimbangan pada penderita stroke berkaitan dengan ketidakmampuan untuk mengatur perpindahan berat badan dan penurunan mobilitas otot. Penderita stroke berulang memiliki masalah dengan kontrol postur tubuh, sehingga menghambar pergerakan. Keseimbangan juga menjadi parameter bagi penderita stroke atas keberhasilan terapi. Penelitian ini untuk membuktikan bahwa core stability exercise with ball dapat meningkatkan keseimbanagn pada pasien stroke. Penelitian ini merupakan penelitian eksperimental dengan pre-test dan post-test grup. Sampel terdiri dari 22 orang, latihan diberikan 3 kali seminggu selama 6 minggu. Keseimbangan diukur dengan Berg Balance Scale Questionnaire (BBS questionnaire). Hasil penelitian ini menunjukkan bahwa core stability exercise with ball meningkatkan keseimbangan pasien stroke secara signifikan $(\mathrm{p}=0.001)$. Sehingga disarankan fisioterapis untuk mengaplikasikannya pada pasien stroke untuk meningkatkan keseimbangan.
\end{abstract}


Kata kunci: Core Stability Exercise, Stroke, Balance

\section{PENDAHULUAN}

Stroke merupakan salah satu pembuluh darah otak yang hingga saat ini dikategorikan sebagai penyebab kematian ketiga setelah penyakit jantung dan kanker juga yang paling membahayakan seta merupakan penyebab kecacatan jangka panjang nomor satu dan penyebab kematian nomor dua di dunia (Hacke, 2003). Stroke merupakan penyakit cerebrovasculer yang mengacu kepada setiap gangguan neurologik mendadak terjadi akibat terbatasnya atau terhentinya aliran darah melalui suplai arteri otak yang dikenal dengan Cerebro Vascular Accident (VSA). Pada penderita yang berusia di atas 45 tahun, stroke paling banyak disebabkan oleh pengerasan pembuluh darah (arterosklerosis). Sedangkan stroke yang menyerang pada usia muda lebih banyak disebabkan oleh cacat pembuluh darah bawaan. Apabila kasus ini tidak ditangani secara cepat dan tepat dapat mengakibatkan penurunan kualitas hidup seseorang atau bahkan kematian. Dua pertiga dari serangan stroke terjadi pada orang di atas 65 tahun. Tetapi tidak berarti stroke hanya terjadi pada orang dengan usia lanjut karena stroke bisa menyerang semua kelompok umur. Faktor jenis kelamin, pria lebih beresiko terkena stroke dibanding wanita, tetapi penelitian menyimpulkan bahwa justru lebih banyak wanita yang meninggal karena stroke. Resiko stroke pria 1,25 lebih tinggi dibanding wanita, tetapi serangan stroke pada pria terjadi usia muda sehingga tingkat kelangsungan hidup juga tinggi (Junaidi, 2012).

Pasien stroke stadium recovery menyebabkan perubahan tonus yang abnormal, penurunan informasi dari fungsi visual, vestibular dan proprioseptif. Adanya abnormal tonus secara postural (spastisitas) maka akan terjadi gangguan gerak. Gangguan sistem informasi (visual, vestibular dan somatosensorik) membuat pasien stroke mengalami kesulitan dalam membedakan jarak, respon sikap untuk mempertahankan titik gravitasi tubuh dan posisi kepalanya, serta terganggunya (input) proprioseptor. Akibat adanya gangguan tersebut dapat berakibat terjadinya gangguan aktifitas fungsional dan dapat gangguan keseimbangan (Mao, 2002).

Gangguan fungsi keseimbangan terutama saat berdiri tegak, merupakan akibat stroke paling berpengaruh pada faktor aktivitas sejak kemampuan keseimbangan tubuh di bidang tumpu mengalami gangguan dalam beradaptasi terhadap gerakan dan kondisi lingkungan (Irfan, 2010). Keseimbangan melibatkan berbagai gerakan di setiap segmen tubuh dengan di dukung oleh sistem muskuloskleletal dan bidang tumpu. Kemampuan untuk menyeimbangkan massa tubuh dengan bidang tumpu akan membuat manusia mampu untuk beraktivitas secara efektif dan efisien (Irdawati, 2012).

Fisioterapi berperan penting dalam mengembalikan dan menjaga aktivitas fungsional pada seseorang dengan keluhan gangguan keseimbangan pada pasien stroke secara optimal dengan cara meningkatkan kekuatan otot, proprioseptif dan kontrol postural. Core stability exercise adalah sebuah latihan yang ditujukan untuk memfasilitasi core muscle yang berfungsi untuk meningkatkan stabilisasi dari kolumna vertebralis untuk menjaga spine dalam posisi netral. Latihan ini difokuskan pada otot-otot lokal yang letaknya lebih dalam (Kisner, 1999).

Salah satu prinsip perkembangan saraf menyatakan bahwa kontrol gerakan dari proksimal ke distal dari bagian tubuh. Trunk menjadi titik kunci pusat tubuh, kontrol trunk merupakan persyaratan untuk kontrol gerakan anggota badan, keseimbangan, dan fungsi 
mobilitas (Davis, 2003). Core muscle memberikan dinamik support ke individual segment pada spine dan membantu menjaga setiap segment pada posisi stabil sehingga jaringan inert tidak mengalamin stress pada keterbatasan gerak. Baik otot-otot global dan otot-otot core berperan dalam memberikan stabilisasi multi segmen pada spine. Hal tersebut menunjukkan bahwa hanya dengan stabilitas postur (aktifasi core muscle) yang optimal, maka mobilitas pada ekstremitas dapat dilakukan dengan efisien.

Berdasarkan uraian di atas maka dilakukan penelitian dengan tujuan untuk membuktikan core stability exercise with ball dapat meningkatkan keseimbangan pada pasien stroke.

\section{METODE PENELITIAN}

Rancangan Penelitian

Penelitian ini merupakan penelitian eksperimental dengan rancangan penelitian pre-test and post-test group design.

\section{Tempat dan Waktu Penelitian}

Penelitian ini dilakukan di Klinik Karmel, Jakarta. Waktu penelitian ini dilaksanakan dari bulan Maret - Mei 2014.

\section{Populasi dan Sampel}

Sampel berjumlah 22 orang dengan kondisi stroke, umur 35-70 tahun, terdapat penyimpangan postur saat berdiri, tidak ada gangguan kognitif, visual, dan pendengaran, serta kemampuan terakhir pasien mampu duduk.

\section{Variabel dan Instrumen Penelitian}

Core stability exercise with ball dilakukan dengan posisi duduk tegak di atas swiss ball. Posisi kaki fleksi $90^{\circ}$, telapak kaki menapak di lantai, kedua tangan diangkat setinggi bahu dan pandangan lurus ke depan. Pertahankan posisi ini selama 1-2 menit. Selanjutnya sampel menggerakkan bola ke depan sampai menyentuh ankle, dengan telapak kaki menapak di lantai. Selanjutnya. Sampel menggerakkan bola ke belakang sampai lutut semi fleksi, dan posisi telapak kaki tetap menapak lantai. Keseimbangan berdiri diukur dengan menggunakan Berg Balance Scale yang terdiri dari 14 jenis tes keseimbangan dengan skala $0-4$, sehingga nilai pada orang normal adalah 56.

HASIL DAN PEMBAHASAN

Karakteristik Subjek Penelitian

Tabel 1 Data Karakteristik Subjek

\begin{tabular}{lll}
\hline & Variabel & Rerata \pm SB \\
\hline Umur (th) & $63,3 \pm 3,746$ & \\
Waktu riwayat (bln) & $18,2 \pm 0,522$ & \\
\hline
\end{tabular}

Berdasarkan Tabel 1 diketahui rerata umur subjek dalam penelitian ini adalah $63,3 \pm 3,746$ tahun. Didapatkan rerata waktu riwayat terjadinya stroke adalah $18,2 \pm 0,522$ bulan. 


\section{Efek Perlakuan}

Tabel 2 Hasil Uji Efek Perlakuan

\begin{tabular}{clc}
\hline Variabel & Rerata \pm SB & $p$ \\
\hline BBS pre & $37,29 \pm 2,563$ & 0,001 \\
BBS post & $44,29 \pm 3,498$ & \\
\hline
\end{tabular}

Hasil uji efek perlakuan seperti yang tampak pada tabel 2 di atas menunjukkan bahwa terdapat perbedaan yang signifikan antara pre dan post berdasarkan hasil $t$-test of related adalah $p<0,05$, sehingga dapat disimpulkan bahwa core stability exercise with ball dapat meningkatkan keseimbangan pada pasien stroke.

\section{PEMBAHASAN}

Core stability exercise with ball dilakukan untuk memperbaiki postur yang tidak simetris tersebut sebelum melakukan sebuah gerakan sehingga gerakan yang ditimbulkan tidak membutuhkan kontraksi dari banyak otot dan keseimbangan dapat terjaga. Postur yang simetris akan mempengaruhi Base Of Support (BOS) dan Center Of Gravity (COG) yang baik sehingga dapat meningkatkan keseimbangan saat berdiri (Carr, 2007).

Core stability memerlukan gerakan trunk control dalam 3 bidang, dalam mempertahankan keseimbangan semua bidang gerak otot-otot teraktivasi dalam pola yang berbeda dari fungsi utamanya. Diantaranya otot quadratus lumborum sebagai stabilisator saat aktivassi dari bidang frontal. Aktivasi otot tersebut terjadi pada gangguan fleksi, ekstensi dan lateral fleksi untuk menopang spine dalam bidang gerak, sehingga membuatnya lebih dari sekedar stabilisasi pada bidang frontal (Davis, 2003).

Trunk menjadi titik kunci sentral tubuh, control trunk merupakan persyaratan untuk kontrol gerakan anggota badan, keseimbangan dan aktivitas fungsional. Trunk control merupakan kemampuan otot trunk untuk memungkinankan tubuh tetap tegak dan menyesuaikan perubahan berat badan, sehingga dapat menjaga pusat massa tubuh selama penyesuaian postural statis dan dinamin (Ryerson, 2008). Studi dengan menggunakan dynamometer isokinetic menunjukkan kelemahan otot fleksor trunk, ekstensor trunk dan rotator bilateral pada pasien pasca stroke (Fukuoka, 2001).

Pemahaman dan kesadaran tentang gerakan yang timbul serta otot stabilisator yang adekuat akan memudahkan untuk mencapai bidang tumpu, garis dan pusat gravitasi serta tekanan dari bidang tumpu yang tepat. Adanya kordinasi tersebut, kemampuan untuk mempertahankan keseimbangan akan lebih mudah (Irfan, 2010)

Penelitian lain yang telah dilakukan dengan menggunakan core stability exercise with ball menguatkan bahwa intervensi ini memang dapat meningkatkan keseimbangan berdiri pada pasien stroke, yaitu penelitian oleh Karthikbabu pada tahun 2011 dengan judul, comparison of physio ball and plinth trunk exercises regimens on trunk control and functional balance in patients with acute stroke.

\section{KESIMPULAN}

Berdasarkan hasil analisis dan pembahasan yang telah dijabarkan sebelumnya, dapat disimpulkan bahwa core stability exercise with ball dapat meningkatkan keseimbangan pada pasien stroke. 


\section{DAFTAR PUSTAKA}

Hacke W, Kaste M, Bogousslavsky J, Brainin M, Chamorro A, Lees K. (2003). Ischemic Stroke Prophylaxis and Treatment. European Stroke Initiative Recommendations.

Junaidi I. (2012). Stroke waspada ancamannya. Yogyakarta: Andi.

Mao H, Hsuses I, Tang P, Sheu C, Hsies C. (2002). Analysis and comparison of the psychometric properties of three balance measure for stroke patients. Stroke. Vol. 33, pp. 1022-1027.

Irfan M. (2010). Fisioterapi bagi insan stroke. Yogyakarta: Graha IImu.

Irdawati. (2012). Pengaruh latihan gerak terhadap keseimbangan pasien stroke non-hemoragik. Jurnal Kesehatan Masyarakat.

Kisner C. (1999). Therapeutic exercise foundation and technique. Philadelpia.

Davis PM. (2003). Problems associated with the loss of selective trunk activity in hemiplegia. Right in the middle. Selective trunk activity in the treatment of adult hemiplegia. Heidelberg: Springer.

Carr JH, Shepherd RB. (2007). Stroke Rehabilitation. Elsevier.

Fukuoka Y, Nagata T, Ishida A, Minamitani H. (2001). Characteristics of somatosensory feedback in postural control during standing. IEEE Trans Neural Syst Rehab.

Ryerson S, Brown D, Wong R, Hidler J. (2008). Altered trunk position sense and its relation to balance functions in people post-stroke. J Neuro Phys Ther. 